\title{
Polymer-mineral scaffold augments in vivo equine multipotent stromal cell osteogenesis
}

Wei Duan', Cong Chen², Masudul Haque, Daniel Hayes ${ }^{2}$ and Mandi J. Lopez ${ }^{1 *}$ (D)

\begin{abstract}
Background: Use of bioscaffolds to direct osteogenic differentiation of adult multipotent stromal cells (MSCs) without exogenous proteins is a contemporary approach to bone regeneration. Identification of in vivo osteogenic contributions of exogenous MSCs on bioscaffolds after long-term implantation is vital to understanding cell persistence and effect duration.

Methods: This study was designed to quantify in vivo equine MSC osteogenesis on synthetic polymer scaffolds with distinct mineral combinations 9 weeks after implantation in a murine model. Cryopreserved, passage (P)1, equine bone marrow-derived MSCS (BMSC) and adipose tissue-derived MSCS (ASC) were culture expanded to P3 and immunophenotyped with flow cytometry. They were then loaded by spinner flask on to scaffolds composed of tricalcium phosphate (TCP)/hydroxyapatite (HA) (40:60; HT), polyethylene glycol (PEG)/ poly-L-lactic acid (PLLA) (60:40; GA), or PEG/PLLA/TCP/HA (36:24:24:16; GT). Scaffolds with and without cells were maintained in static culture for up to 21 days or implanted subcutaneously in athymic mice that were radiographed every 3 weeks up to 9 weeks. In vitro cell viability and proliferation were determined. Explant composition (double-stranded (ds)DNA, collagen, sulfated glycosaminoglycan (sGAG), protein), equine and murine osteogenic target gene expression, microcomputed tomography $(\mu \mathrm{CT})$ mineralization, and light microscopic structure were assessed.

Results: The ASC and BMSC number increased significantly in HT constructs between 7 and 21 days of culture, and BMSCs increased similarly in GT constructs. Radiographic opacity increased with time in GT-BMSC constructs. Extracellular matrix (ECM) components and dsDNA increased significantly in GT compared to HT constructs. Equine and murine osteogenic gene expression was highest in BMSC constructs with mineralcontaining scaffolds. The HT constructs with either cell type had the highest mineral deposition based on $\mu C T$. Regardless of composition, scaffolds with cells had more ECM than those without, and osteoid was apparent in all BMSC constructs.
\end{abstract}

Conclusions: In this study, both exogenous and host MSCs appear to contribute to in vivo osteogenesis. Addition of mineral to polymer scaffolds enhances equine MSC osteogenesis over polymer alone, but pure mineral scaffold provides superior osteogenic support. These results emphasize the need for bioscaffolds that provide customized osteogenic direction of both exo- and endogenous MSCs for the best regenerative potential.

Keywords: Bone, Adipose, Bioreactor, Murine, Computed tomography, Microstructure

\footnotetext{
* Correspondence: mlopez@lsu.edu

${ }^{1}$ Laboratory for Equine and Comparative Orthopedic Research, Louisiana

State University, Baton Rouge, LA, USA

Full list of author information is available at the end of the article
} 


\section{Background}

A viable graft composed of adult multipotent stromal cells (MSCs) and biocompatible scaffold is a promising approach to enhance natural bone formation and augment current treatment strategies for equine traumatic bone injury $[1,2]$. Autologous autograft promotes bone formation by local cells, but harvest morbidity in addition to variable cell survival and graft quantity and quality help fuel the search for regenerative medicine alternatives [3, 4]. Osteogenic capabilities of equine bone marrow-derived MSCs (BMSCs) and adipose-derived MSCs (ASCs) vary with culture conditions and scaffold carriers [5-8]. Given the inherent responsiveness of undifferentiated cells to their surroundings $[1,4,9]$, it is vital to confirm in-vitro MSC characteristics in vivo. This is especially true since cell-based therapies are designed to enhance bone healing in potentially unfavorable conditions.

The natural bone fracture environment has over 200 noncollagenous matrix proteins and collagen and hydroxyapatite (HA) nanostructure that guides native progenitor cell osteogenesis [9]. Through structure and composition, functional scaffolds create a biomimetic environment for endo- and exogenous cells [9-14]. Mineral-based scaffolds have good biomimetic characteristics, but brittle mechanical properties complicate implant customization, surgical stabilization, and biological incorporation [15]. Scaffolds composed of both synthetic polymers and minerals such as HA and tricalcium phosphate (TCP) have biomimetic characteristics of inorganic matrix but greater flexibility $[15,16]$. A scaffold composition that supports consistent, predictable tissue formation by MSCs from distinct tissues and donors is appealing for clinical application.

Poly-L-lactic acid (PLLA) and polyethylene glycol (PEG) are biocompatible, nontoxic polyester polymers $[17,18]$. Distinct PLLA:PEG ratios have predictable hydrolytic degradation [19-23]. Addition of HA to PLLA scaffolds enhances murine osteoblast cell line protein adsorption, suppresses cell apoptosis, and enhances survival, growth, and osteogenic gene expression [24, 25]. Composite PLLA/TCP scaffold increases endogenous alkaline phosphatase (ALP) activity in human ASCs over PLLA alone [14]. Information about equine MSCscaffold osteogenesis is relatively limited [26], but this contemporary knowledge supports a potential for polymer-mineral scaffold carriers to support the process [20].

Homogenous distribution of viable MSCs throughout scaffold carriers is crucial for organized tissue matrix production [27]. Bioreactor dynamic cell loading under optimal conditions limits cell loss and ensures distribution [28] important for neovascularization and de novo tissue formation [29]. Spinner flask bioreactors limit cell cluster formation, facilitate uniform cell seeding, and support nutrient and waste exchange [30, 31]. Additionally, exposure to fluid flow for as little as 15 min upregulates murine MSC osteogenic gene expression [32, 33]. Hence, spinner flasks provide an efficient mechanism for consistent construct loading that may help drive osteoblastic differentiation and maturation.

Given the potential of equine ASCs and BMSCs to augment bone generation [34, 35], targeted work is necessary to identify polymer-mineral bioscaffold carriers $[36,37]$ that reliably promote equine MSC osteogenesis in vivo. This study was designed to quantify osteogenesis by equine ASCs and BMSCs on scaffold carriers composed of TCP/HA (40:60; HT; Scaffdex ${ }^{\mathrm{Tm}}$ Ltd., Tampere, Finland), PEG/PLLA (60:40; GA) and PEG/PLLA/TCP/HA (36:24:24:16; GT) in an athymic mouse model. The tested hypothesis was that osteogenesis is comparable on GA and GT scaffolds with either ASCs or BMSCs and greater than on HT scaffolds with either cell type. It was further hypothesized that the same scaffolds with MSCs have greater osteogenesis than those without.

\section{Methods}

Study design

Cell passage (P) 1 cryopreserved equine BMSCs and ASCs were culture expanded to P3. Cells were loaded onto one commercially available mineral (HT) and two novel polymer-mineral scaffolds (GA and GT) via a spinner flask bioreactor. Passage 3 immunophenotype and cell viability on scaffolds after 7 and 21 days of static culture were determined. Scaffolds with and without cells were implanted subcutaneously in athymic mice. Radiographs were performed immediately and then every 3 weeks up to 9 weeks. Explants were evaluated for composition (double-stranded (ds)DNA, total collagen, sulfated proteoglycan, protein), osteogenic target gene mRNA expression (ALP, bone sialoprotein (BSP), osteocalcin (OCN), osteoprotegerin (OPG)), calcium and phosphorus content, and ultra- and microstructure. All materials and reagents were from Sigma-Aldrich, St. Louis, MO, USA, unless otherwise noted.

\section{Scaffold preparation (PEG/PLLA, GA; PEG/PLLA/TCP/HA, GT)} Scaffolds were fabricated through thermally induced phase separation (TIPS) as previously described [38]. Key components included PLLA [(C3H6O3)n, molecular weight $(\mathrm{MW})$ 100,000- 150,000 g/mole], PEG [H(OCH2CH2)nOH, MW 1,900-2,200 g/mole], unsintered nano-sized HA (MW $=502.31 \mathrm{~g} / \mathrm{mole})$, and unsintered nano-sized $\beta$-TCP ( $\mathrm{MW}=310.18 \mathrm{~g} / \mathrm{mole})$. The phase composition of HA and $\beta$-TCP powders were determined with an X-ray diffractometer (XRD; X'Pert PRO, PANalytical Co., Netherlands) employing $\mathrm{Cu}-\mathrm{K} \alpha$ 
radiation $(45 \mathrm{kV}, 40 \mathrm{~mA})$. Data were collected from $10^{\circ}$ to $90^{\circ}$ for $2 \Theta$ with a step size of $0.026^{\circ}$.

\section{PEG/PLLA (60:40)}

Solutions of $10 \%$ PEG and 10\% PLLA in 1,4-dioxane (AcroSeal $^{\text {tw }}$, ACROS Organics) were combined at a ratio of $6: 4(\mathrm{v} / \mathrm{v})$ with stirring at $85{ }^{\circ} \mathrm{C}$ to create a homogenous mixture.

\section{PEG/PLLA/TCP/HA (36:24:24:16)}

TCP was added to $10 \%$ PEG at a ratio of 4:6 (TCP:PEG, $\mathrm{w} / \mathrm{w}$ ) and HA to 10\% PLLA at a ratio of 4:6 (HA:PLLA, $\mathrm{w} / \mathrm{w})$ under the same conditions as above. Solutions were combined at a ratio of 6:4 (TCP-PEG:HA-PLLA), added to polydimethylsiloxane tubes (inner diameter 10 $\mathrm{mm}$, depth $10 \mathrm{~mm}$ ), and unidirectionally frozen by lowering the sample into liquid nitrogen from one end to provide a unidirectional porous structure. Samples were maintained at $-80{ }^{\circ} \mathrm{C}$ overnight and subsequently lyophilized for $48 \mathrm{~h}$ to remove the solvent. Tubular scaffolds were sliced into discs (diameter $10 \mathrm{~mm}$, depth $3 \mathrm{~mm}$ ) that were individually packaged and sterilized with ethylene oxide at $57{ }^{\circ} \mathrm{C}$ for $2 \mathrm{~h}$.

\section{Tissue harvest, cell expansion, cryopreservation}

Sternal bone marrow and subcutaneous adipose tissue were harvested from seven thoroughbred geldings ( $6.3 \pm$ 1.7 years of age; mean \pm standard error of the mean (SEM)) as previously described [8]. Briefly, horses were sedated (detomidine $\mathrm{HCl}, 0.04 \mathrm{mg} / \mathrm{kg}$ intravenously (IV)), the sternebrae aseptically prepared, and $6 \mathrm{ml}$ of $2 \%$ lidocaine chloride infiltrated into the soft tissues. With 14 G Jamshide needles, bone marrow was aspirated into heparinized syringes $(1000 \mathrm{IU} / 60 \mathrm{ml}$ bone marrow aspirate). Next, skin and subcutaneous tissues dorsolateral to the base of the tail were infiltrated with $2 \%$ lidocaine chloride. Skin was incised for $10 \mathrm{~cm}$ parallel to and approximately $15 \mathrm{~cm}$ lateral to the dorsal sacrum, and exposed subcutaneous adipose tissue (15$20 \mathrm{ml}$ ) was sharply excised. The skin was apposed with \#2 nylon.

Cells were isolated as previously published with minor modifications [8]. Bone marrow aspirate combined with an equal volume of stromal medium (Dulbecco's modified Eagle's medium F-12 (DMEM/F-12, Hyclone, Logan, UT, USA), 1\% antibiotic/antimycotic solution (MP Biomedical, Irvine, CA, USA), 10\% fetal bovine serum (FBS; Hyclone)) was separated via centrifugation $\left(350 \times \mathrm{g}, 4{ }^{\circ} \mathrm{C}, 30 \mathrm{~min}\right)$ with Ficoll-Paque ${ }^{\circ}$ PLUS (Stem Cell Technologies, Vancouver, Canada). The cell layer was removed and centrifuged $\left(260 \times \mathrm{g}, 4{ }^{\circ} \mathrm{C}, 5 \mathrm{~min}\right)$ to form a cell pellet that was seeded in T75 flasks $\left(5 \times 10^{3}\right.$ cells $\left./ \mathrm{cm}^{2}\right)$ for culture. Stromal medium was refreshed after $24 \mathrm{~h}$ and then every 3 days. In this study, P0 is the first cell passage of primary cells. Procedures performed at temperatures other than room temperature are indicated.

Minced adipose tissue was combined with an equal volume of phosphate-buffered saline (PBS; Hyclone). After the mixture separated into two phases over $5 \mathrm{~min}$, the infranatant was digested in $1 \%$ bovine serum albumin (BSA; Fisher Bioreagents, Fair Lawn, NJ, USA) and 0.1\% collagenase type I (Worthington Biochemical Corporation, Lakewood, NJ, USA) in DMEM/F-12 for $2 \mathrm{~h}$ at $37{ }^{\circ} \mathrm{C}$. After filtering $(100-\mu \mathrm{m}$ nylon cell strainers; BD Falcon, Bedford, MA, USA) and centrifugation $(260 \times \mathrm{g}, 5 \mathrm{~min})$, cells in DMEM with 1\% BSA were added to an equal volume of red blood cell lysis buffer $\left(0.16 \mathrm{~mol} / \mathrm{L} \mathrm{NH}_{4} \mathrm{Cl}, 0.01\right.$ $\mathrm{mol} / \mathrm{L} \quad \mathrm{KHCO}_{3}, \quad 0.01 \%$ ethylenediaminetetraacetic acid (EDTA)) for $5 \mathrm{~min}$. The stromal vascular fraction (SVF) was collected after centrifugation $(260 \times \mathrm{g}, 5 \mathrm{~min})$ and cultured as above.

At $70 \%$ confluence, cells were detached with $0.05 \%$ trypsin (Hyclone), suspended in cryopreservation medium (80\% FBS, 10\% DMEM/F-12, 10\% dimethyl sulfoxide (DMSO; Fisher Scientific, Fair Lawn, NJ, USA) at $1-1.5 \times 10^{6}$ cells $/ \mathrm{ml}$ and aliquoted into $1.5-\mathrm{ml}$ cryovials (Fisher Scientific). Cells were cooled to $-80^{\circ} \mathrm{C}$ at approximately $-1{ }^{\circ} \mathrm{C} / \mathrm{min}$ (CoolCell ${ }^{\circ}$, BioCision, Larkspur, CA, USA) overnight and then transferred to liquid nitrogen for 33-45 days. To thaw, cryovials were placed in a $37{ }^{\circ} \mathrm{C}$ water bath for $1-2$ min followed by centrifugation $(380 \times \mathrm{g}, 5 \mathrm{~min})$, a PBS wash, another centrifugation $(380 \times \mathrm{g}, 5 \mathrm{~min})$, and then stromal medium culture.

\section{Immunophenotype: flow cytometry}

Passage 3 revitalized ASCs and BMSCs from three equine donors were combined in equal proportions within cell type for immunophenotype detection. Aliquots of $1 \times 10^{5}$ cells in $150 \mu \mathrm{l}$ PBS were incubated for $30 \mathrm{~min}$ at room temperature with $200 \mu \mathrm{g} / \mathrm{ml}$ labeled or unlabeled antibody (CD34-PE, CD29, CD73-FITC, CD44-FITC, CD90-PE, CD105-PE) specific or validated cross-reactive for equine antigens (Table 1 ). Cells were rinsed with PBS, centrifuged $(350 \times \mathrm{g}, 5 \mathrm{~min})$, and fixed with $4 \%$ neutral buffered formalin. For CD29, cells were incubated with labeled anti-immunoglobulin (IgG-FITC) for $30 \mathrm{~min}$, rinsed with PBS, centrifuged $(350 \times \mathrm{g}$, 5 min), and fixed with $4 \%$ neutral buffered formalin. Cell fluorescence was quantified using a FACSCalibur flow cytometer and Cell Quest Pro software (BD Biosciences, San Jose, CA, USA). Autofluorescence was determined on antibody-negative samples.

\section{Construct seeding and culture}

P1 revitalized ASCs and BMSCs were culture expanded to P3 and then loaded onto scaffolds $\left(1 \times 10^{6}\right.$ cells/scaffold) for $2 \mathrm{~h}$ with $70 \mathrm{rpm}$ stirring in spinner flask bioreactors $\left(37{ }^{\circ} \mathrm{C}, 5 \% \mathrm{CO}_{2}\right)$. Spinner flasks consisted of 
Table 1 Flow cytometry antibodies

\begin{tabular}{|c|c|c|c|c|c|c|}
\hline Antibody & Label & Marker expression & Manufacturer & Origin species & Target species & Diluent \\
\hline CD29 & N/A & $\beta 1$ integrin & BD Biosciences & Mouse & Canine & PBS \\
\hline CD44 & FITC & Cell-surface glycoprotein, hyaluronic acid receptor & eBioscience & Mouse & Canine & PBS \\
\hline CD73 & FITC & 5'-Nucleotidase & eBioscience & Mouse & Human & PBS \\
\hline CD90 & PE & Thy-1, fibroblasts, MSC, HSC & eBioscience & Mouse & Canine & PBS \\
\hline CD105 & PE & Type 1 glycoprotein & eBioscience & Mouse & Human & PBS \\
\hline CD34 & PE & $\mathrm{HSC}$ & BD Biosciences & Mouse & Canine & PBS \\
\hline $\lg G$ & FITC & N/A & Sigma & Rabbit & Mouse & PBS \\
\hline
\end{tabular}

FITC fluorescein isothiocyanate, HSC hematopoietic stem cell, IgG immunoglobulin, MSC multipotent stromal cell, N/A not applicable, PBS phosphate-buffered saline, PE phycoerythrin

100-ml flasks (Bellco ${ }^{\circ}$ Biotechnology, Newark, NJ, USA) containing $120 \mathrm{ml}$ of serum-free stromal medium and three separate 4-inch-long, 22-gauge spinal needles suspended from a rubber stopper at the top of each flask that each passed through the center of one scaffold (Fig. 1). Individual loading processes for scaffolds without cells, pooled aliquots identical to those used for immunophenotype, and for each cell tissue source and donor included one scaffold of each composition situated at the middle of the fluid. Specifically, there was one scaffold per donor (individual (7), pooled (2)/tissue source (BMSC, ASC, none)/composition (HT, GA, GT)) for a total of 81 samples. After $2 \mathrm{~h}$, loading efficiency was determined and cellscaffold constructs divided into six equal pieces for immediate evaluation, culture in stromal medium, or implantation as described below.

Cell number via 3-(4,5-dimethylthiazol-2-yl)-2,5-diphenyl tetrazolium bromide (MTT)

Commercially available MTT (Cell Proliferation Kit I) was used to determine cell number immediately after cell loading or following 7 or 21 days of stromal medium culture in 24-well culture plates (two pooled isolates from three donors/cell tissue source/scaffold composition divided into six pieces for four replicates per time point). Briefly, constructs were gently rinsed with PBS and placed into fresh plates followed by incubation with $500 \mu \mathrm{l}$ of a 5:1 mixture of stromal medium and MTT solution ( $5 \mathrm{mg} / \mathrm{ml}$ in PBS) for $2 \mathrm{~h}\left(37{ }^{\circ} \mathrm{C}, 5 \% \mathrm{CO}_{2}\right)$. Subsequently, $500 \mu \mathrm{l}$ of DMSO was added to each well, the absorbance read at $540 \mathrm{~nm}$ (Synergy HT, BioTek Instruments, Winooski, VT, USA), and the cell number determined from equine ASC or BMSC standard curves. Cell number fold-change was calculated as $C_{\mathrm{f}} / \mathrm{C}_{\mathrm{i}}\left(\mathrm{C}_{\mathrm{f}}=\right.$ cell number after 7 or 21 days of culture; $\mathrm{C}_{\mathrm{i}}=$ cell number immediately after scaffold loading).

\section{Scaffold surgical implantation}

One scaffold divided into six pieces for each donor (7)/ tissue source (BMSC, ASC, none)/composition (GA, GT, HT) was surgically implanted in the dorsal subcutaneous tissues of 63 male athymic mice $(\mathrm{nu} / \mathrm{nu}$, Charles River Laboratories, Wilmington, MA, USA) (Table 2). Implants were harvested 9 weeks after surgery and evaluated. Implants from each mouse were assessed for gene expression ( $n=2$ implants/mouse), composition ( $n=2$ implants/mouse), ultrastructure ( $n=1 \mathrm{implant} /$ mouse), and microstructure ( $n=1 \mathrm{implant} /$ mouse).

Mice were premedicated (glycopyrrolate, $0.02 \mathrm{mg} /$ $\mathrm{kg}$; butorphanol, $0.5 \mathrm{mg} / \mathrm{kg}$, both subcutaneously) and anesthetized with isoflurane on oxygen delivered via a Baine circuit and mask. Following aseptic preparation, six 5-mm skin incisions were created equidistantly along the dorsum extending from the scapula to the sacrum approximately $1 \mathrm{~cm}$ ventral to each side of the spine. Following minimal blunt dissection, scaffolds were placed beneath the skin, subcutaneous tissues closed with \#3-0 nylon, and the skin apposed with tissue glue.

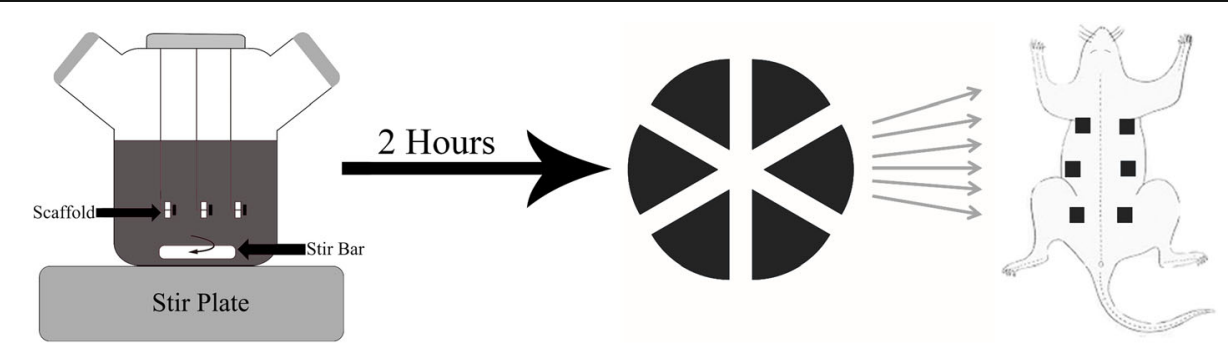

Fig. 1 Schematic of spinner flask bioreactor cell loading, scaffold division, and implantation 
Table 2 In-vivo study design

\begin{tabular}{|c|c|c|c|c|c|c|c|}
\hline \multirow[t]{2}{*}{ Scaffold } & \multicolumn{3}{|c|}{ Cell component } & \multicolumn{4}{|c|}{ Analyses for individual mouse implants ( 6 per mouse) } \\
\hline & None & BMSC & ASC & Gene expression & Composition & Ultrastructure & Microstructure \\
\hline $\begin{array}{l}\text { HT } \\
40: 60 \\
\beta \text { tricalcium phosphate:hydroxyapatite }\end{array}$ & 7 mice & 7 mice & 7 mice & 2/6 implants & 2/6 implants & 1/6 implants & $1 / 6$ implants \\
\hline $\begin{array}{l}\text { GA } \\
60: 40 \\
\text { polyethylene glycol:poly-L-lactic acid }\end{array}$ & 7 mice & 7 mice & 7 mice & 2/6 implants & 2/6 implants & 1/6 implants & 1/6 implants \\
\hline $\begin{array}{l}\text { GT } \\
\text { 36:24:24:16 } \\
\text { polyethylene glycol:poly-L-lactic acid: } \\
\beta \text { tricalcium phosphate:hydroxyapatite }\end{array}$ & 7 mice & 7 mice & 7 mice & 2/6 implants & 2/6 implants & 1/6 implants & $1 / 6$ implants \\
\hline
\end{tabular}

\section{Radiographs: mineral deposition}

Radiographs (Sound Technologies, Carlsbad, CA, USA) were performed immediately and 3, 6, and 9 weeks after surgery with mice in ventral recumbency and anesthetized as described above. Mineral deposition was subjectively assessed based on changes in radiopacity.

\section{Microcomputed tomography: porosity, bone volume/total volume}

Two- and three-dimensional images generated from a microcomputed tomography $(\mu \mathrm{CT})$ scanner $(\mu \mathrm{CT} 40$; Scanco Medical AG, Bassersdorf, Switzerland) and graphics software (Mimics ${ }^{\ominus}$ Materialise, Ann Arbor, MI, USA) were used to quantify specimen percent porosity and bone volume/total volume (BV/TV; $\mu$ CT Evaluation Program V6.6), respectively, 9 weeks after implantation. Imaging technique $(55 \mathrm{kV}, 145 \mu \mathrm{A})$ and two-dimensional 16-bit grayscale threshold were identical among samples. Percent porosity was measured on slices at 25,50 , and $75 \%$ of the total specimen height. The mean of the three values was used as the measure for each specimen. To distinguish between high-contrast scaffold versus lowcontrast newly deposited tissue, two thresholds were used for three-dimensional image reconstructions of GT $\left(170,370 \mathrm{mg} \mathrm{HA} / \mathrm{cm}^{3}\right)$ and $\mathrm{HT}\left(380,590 \mathrm{mg} \mathrm{HA} / \mathrm{cm}^{3}\right)$ samples. The difference in the BV/TV between thresholds was considered as a measure of new tissue deposition. A single threshold $\left(270 \mathrm{mg} \mathrm{HA} / \mathrm{cm}^{3}\right)$ was used for GA constructs which did not contain highcontrast material.

\section{Compositional analysis: DNA, hydroxyproline, sulfated glycosaminoglycan, protein}

Compositional analysis was performed as per previous reports [39]. Briefly, constructs were lyophilized at $-55{ }^{\circ} \mathrm{C}$ and 0.2 mbar for $4-5 \mathrm{~h}$ and then $20 \mathrm{mg}$ of each sample was digested ( $9 \mathrm{mM}$ di-sodium EDTA, $20 \mathrm{mM}$ sodium acetate, $20 \mathrm{mM}$ L-cysteine (MP Biomedicals, Solon, OH, USA), $2 \mathrm{mg}$ papain (MP Biomedicals) per gram lyophilized sample) at $60{ }^{\circ} \mathrm{C}$ for $10 \mathrm{~h}[40,41]$. Digested samples were vigorously vortexed and then centrifuged $(4000 \times \mathrm{g}$,
$10 \mathrm{~min})$. Supernatants were stored at $-80^{\circ} \mathrm{C}$ until analysis. Double-stranded DNA was determined with a commercially available kit (Quant-iT ${ }^{\mathrm{mm}}$ PicoGreen ${ }^{\circ}$ Kit, Invitrogen, Carlsbad, CA, USA) [41]. Hydroxyproline content as a measure of total collagen was quantified via Ehrlich's colorimetric assay and absorbance at $550 \mathrm{~nm}$ based on trans4-hydroxy-L-proline (ACROS Organics ${ }^{\mathrm{TM}}$, Morris Plains, NJ, USA) standards [41, 42]. Sulfated glycosaminoglycan (sGAG) was quantified with a dimethylmethylene blue (DMMB) assay, with absorbance at $520 \mathrm{~nm}$ and a chondroitin sulfate standard curve $[41,43]$. Lowry's total protein assay with Biuret's and Folin-Ciocalteu's reagents, absorbance at $650 \mathrm{~nm}$, and bovine serum albumin standards, was used to quantify sample protein [44].

Scanning electron microscopy: ultrastructure, phosphate, calcium

Samples were fixed with $2.5 \%$ glutaraldehyde in $0.1 \mathrm{M}$ sodium cacodylate buffer ( $\mathrm{pH} 7.4$ ), post-fixed in $0.1 \%$ osmium tetroxide, and then dehydrated in a series of ethanol-distilled water solutions [8]. After critical point drying, they were sputter coated with gold and imaged (FEI Quanta 200, Netherlands). Surface calcium and phosphorus was measured in the center of each sample by energy-dispersive $\mathrm{x}$-ray spectroscopy (EDS; $20 \mathrm{kV}, 3 \%$ accuracy) [45].

\section{Real-time polymerase chain reaction (RT-PCR): gene expression}

Total RNA was isolated from harvested samples (RNeasy Plus Mini Kit, Qiagen, GmbH, Germany), the concentration was determined spectrophotometrically (NanoDrop ND-1000; NanoDrop Technologies, Wilmington, DE, USA), and cDNA synthesized (QuantiTect Reverse Transcription Kit, Qiagen). Equine and murine osteogenic target gene levels (ALP, OCN, BSP, and OPG; Table 3) were quantified with RT-PCR using SYBR Green (Qiagen) technology and an MJ Research Chromo 4 Detector (Bio-Rad Laboratories, Hercules, CA, USA). Primers were designed according to species-specific genetic sequences. Each primer was tested with bone RNA 
Table 3 Primer sequences

\begin{tabular}{lllll}
\hline Species & Lineage & Primer & Sequence & Accession number \\
\hline Equine & Reference & GAPDH & Forward: AAGAAGGTGGTGAAGCAGGReverse: CTCAGTGTAGCCCAGGATG & NM_001163856.1 \\
& Osteogenesis & ALP & Forward: GGAGTATGAGATGGACGAGReverse: GTAGTGAGAGTGCTTGTGCC & XM_005607380.2 \\
& & OCN & Forward: TGGCCCTGACTGCATTCTGReverse: CCCTCCTGCTTGGACATGAA & XM_005610022.1 \\
& & OPG & Forward: CCCCCCTTGTCTGACCACTReverse: CGCCCTTCCTCACATTCG & XM_001916099.4 \\
& & BSP & Forward: GAAGAATCGGACGCTGAGReverse: ATCGTAGACAGGGTGGTG & XM_001496125.4 \\
Murine & Reference & GAPDH & Forward: ACCCAGAAGACTGTGGATGGReverse: ACACATTGGGGGTAGGAACA & XM_017321385.1 \\
& Osteogenesis & ALP & Forward: TGATGTGGAATACGAACTGGReverse: TGGGAATGCTTGTGTCTG & XM_006538500.2 \\
& & OCN & Forward: CCATCTTTCTGCTCACTCTGReverse: TTATTGCCCTCCTGCTTG & NM_007541.3 \\
& & OPG & Forward: CACTCGAACCTCACCACAGAReverse: GCTCGATTGCAGGTCTTC & NM_008764.3 \\
& & BSP & Forward: CAGCCATGAGTCAAGTCAGCReverse: CTTGTGGCTCTGATGTTCCA & NM_001204203.1 \\
\hline
\end{tabular}

$A L P$ alkaline phosphatase, BSP bone sialoprotein, GAPDH glyceraldehyde 3-phosphate dehydrogenase, OCN osteocalcin, OPG osteoprotegerin

to confirm the lack of cross-reactivity. The $\Delta \mathrm{Ct}$ values were determined relative to the reference gene glyceraldehyde 3-phosphate dehydrogenase (GAPDH).

\section{Light microscopy: microstructure}

Following fixation in $4 \%$ neutral buffered formalin, serial sections $(5 \mu \mathrm{m})$ of paraffin-embedded specimens were stained with Masson's trichrome. Digital images were generated of all specimens (Leica DM 4500B, Allendale, NJ, USA).

\section{Statistical analysis}

Statistical analyses were performed with the JMP statistical package (v13.0.0, SAS Institute, Cary, NC, USA). Mixed analysis of variance (ANOVA) models were used to evaluate cell number fold-change, composition (dsDNA, total collagen, sulfated proteoglycan, protein), gene expression, porosity, and BV/TV among scaffold compositions within cell tissue sources and between cell tissue sources within scaffold compositions. Fixed effects included scaffold composition and cell tissue source; equine donor and mouse were random effects. Tukey's post-hoc tests were applied for multiple group comparisons $(p<0.05$ was considered significant).

\section{Results}

Immunophenotype: flow cytometry

The majority of P1 ASCs and BMSCs were CD29 ${ }^{+}$, $\mathrm{CD}_{105}{ }^{+}, \mathrm{CD}^{-} 4^{-}, \mathrm{CD}^{-}{ }^{-}$(Fig. 2). There were higher percentages of $\mathrm{C} 90^{+}, \mathrm{CD} 105^{+}, \mathrm{CD} 44^{+}$ASCs (Table 4).

\section{Cell number: MTT}

The ASC and BMSC loading efficiencies were $81.2 \pm$ $11.4 \%$ and $83.4 \pm 4.4 \%$, respectively. The ASC and BMSC number increased significantly in HT constructs between 7 and 21 days of culture, and BMSCs increased similarly in GT constructs (Fig. 3). After 7 days, the increase in BMSC number was greater in HT versus the other scaffolds, and after 21 days, the increase in GA was lower than the other two.

\section{Radiographs: mineral deposition}

All GA scaffolds and GT scaffolds with ASCs or without cells remained radiolucent throughout the study. Those GT scaffolds with BMSCs became radiopaque 6 weeks after implantation. Scaffolds composed of HT were radiopaque throughout the study, and scaffold margins became rounded with time (Fig. 4).

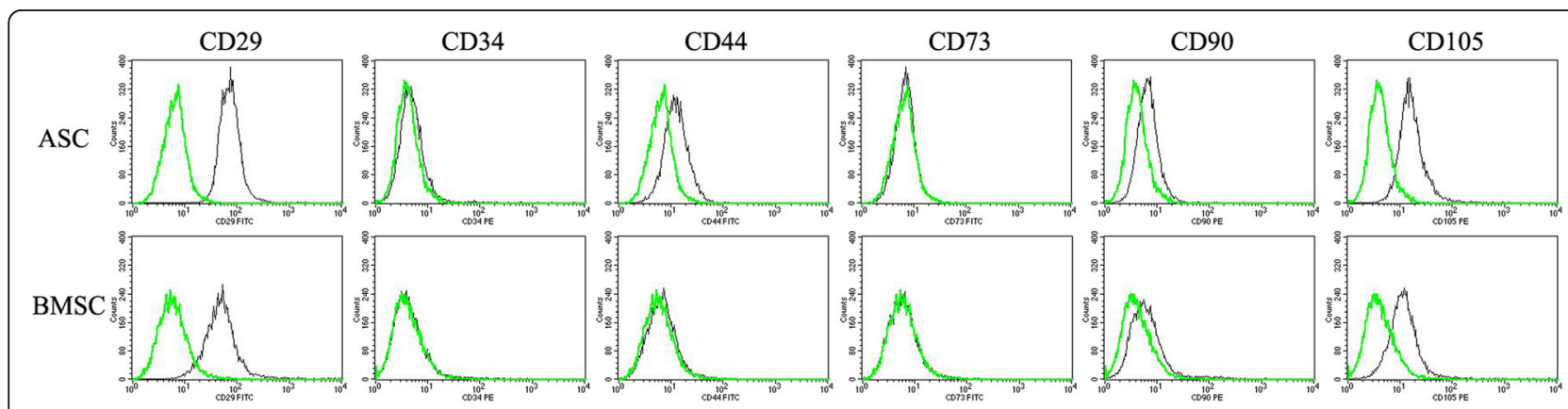

Fig. 2 Immunophenotypes of P3 equine adipose-derived multipotent stromal cells (ASCs) and bone marrow-derived multipotent stromal cells (BMSCs) after culture expansion post-cryopreservation. The black lines represent labeled cells and the green lines represent autofluorescence 
Table 4 Percentages of $\mathrm{CD} 29^{+}, \mathrm{CD}_{4} 4^{+}, \mathrm{CD} 90^{+}, \mathrm{CD} 105^{+}, \mathrm{CD} 34^{-}$, CD73- P3 equine ASCs and BMSCs after post-cryopreservation culture expansion

\begin{tabular}{lllllll}
\hline & $\mathrm{CD} 29^{+}$ & $\mathrm{CD}_{4}$ & ${\mathrm{CD} 44^{+}}^{+}$ & $\mathrm{CD} 73^{-}$ & ${\mathrm{CD} 90^{+}}^{+}$ & ${\mathrm{CD} 105^{+}}^{-}$ \\
\hline ASC & 99 & 83.5 & 11.0 & 99.8 & 46.2 & 87.7 \\
BMSC & 90.3 & 97.9 & 1.5 & 99.9 & 28.2 & 58.8 \\
\hline
\end{tabular}

ASC adipose-derived multipotent stromal cell, BMSC bone marrow-derived multipotent stromal cell

\section{$\mu \mathrm{CT}$ : porosity and BV/TV}

There were measurable differences between BV/TV of GT and HT constructs at low and high thresholds, while BV/TV in GA constructs were only detectable at a high threshold (Fig. 5). The HT constructs had the highest percent porosity (Fig. 6a). Within scaffold compositions, GA and GT scaffolds with cells had higher porosity than those without, while HT scaffolds without cells had higher porosity than HT-BMSC constructs. Direct comparisons among scaffold BV/ TV was not possible due to distinct thresholds used to create reconstructions. Within scaffold compositions, GT- and HT-BMSC constructs had the highest $\mathrm{BV} / \mathrm{TV}$, and GT-ASC constructs had higher BV/TV than those with no cells (Fig. 6b).

\section{Compositional analysis: DNA, hydroxyproline, sGAG, protein} Significant differences in extracellular matrix (ECM) within scaffold composition included higher hydroxyproline (collagen) in GT-ASC constructs versus those without cells (Fig. 7b), higher protein in GT-ASC constructs versus no cells or BMSCs, and higher protein in HT scaffolds without cells versus either ASC or BMSC constructs (Fig. 7d). Differences among scaffolds within cell types included higher dsDNA in GT versus GA or HT scaffolds without cells, in GT versus HT scaffolds with ASCs, and in GA versus HT scaffolds with BMSCs (Fig. 7a). Hydroxyproline was higher in $H T$ versus GA scaffolds without cells and GT versus GA or HT scaffold with ASCs (Fig. 7b). Both GA and GT scaffolds with ASCs or BMSCs had higher sGAG than HT with the same cells (Fig. 7c). Protein was higher in HT versus GA scaffolds without cells and GT versus GA or HT with ASCs (Fig. 7d).

\section{Scanning electron microscopy: ultrastructure, phosphate,} calcium

The XRD patterns of the HA and $\beta$-TCP were consistent with the manufacturer's description with $19.3 \%$ and $6.3 \%$ crystallinity, respectively. Collagen fibrils and amorphous matrix were apparent in all explants (Fig. 8). A notable distinction was the presence of solid regions in various stages of mineralization and surrounded by randomly oriented collagen fibrils in scaffolds with cells. The well-delineated regions were distinct from the more proteinaceous ECM of scaffolds without cells. Subjectively, the BMSC construct ECM was the most dense among the explants.

Within HT-BMSC and GA and GT constructs, calcium and phosphorus percentages were higher and lower, respectively, in scaffolds with versus without cells (Fig. 9), and ratios did not change appreciably in HTASC constructs. The calcium phosphorus ratio was closest to that of HA (1.6) in GA-BMSC and GT-BMSC constructs [46].

\section{RT-PCR: gene expression \\ Equine}

There was no detectable equine gene expression in scaffolds without cells. Osteogenic gene expression tended to be highest in scaffolds with BMSCs and varied among scaffold compositions. Within scaffold compositions, BMSC constructs had higher ALP and OCN than ASC constructs (Fig. 10a, b). The OPG and BSP expression was highest in GT- and HTBMSC constructs, respectively (Fig. 10c, d). Within cell tissue source, ALP was higher in HT- versus GAASC constructs (Fig. 10a). Both ALP and OCN were
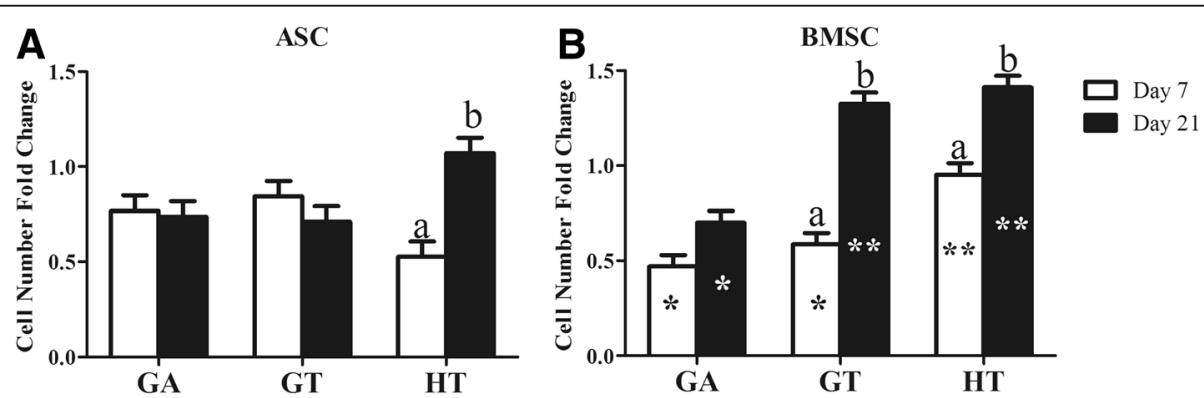

Fig. 3 Fold-change in adipose-derived multipotent stromal cell (ASC; a) or bone marrow-derived multipotent stromal cell (BMSC; b) number after 7 or 21 days of static culture in stromal medium on scaffolds composed of tricalcium phosphate (TCP)/hydroxyapatite (HA) (40:60; HT), polyethylene glycol (PEG)/poly-L-lactic acid (PLLA) (60:40; GA), or PEG/PLLA/TCP/HA (36:24:24:16; GT). Columns with distinct superscripts are significantly different between culture times within scaffold composition and those with different asterisk $(*)$ numbers are significantly different among scaffold compositions within culture time $(p<0.05)$ 


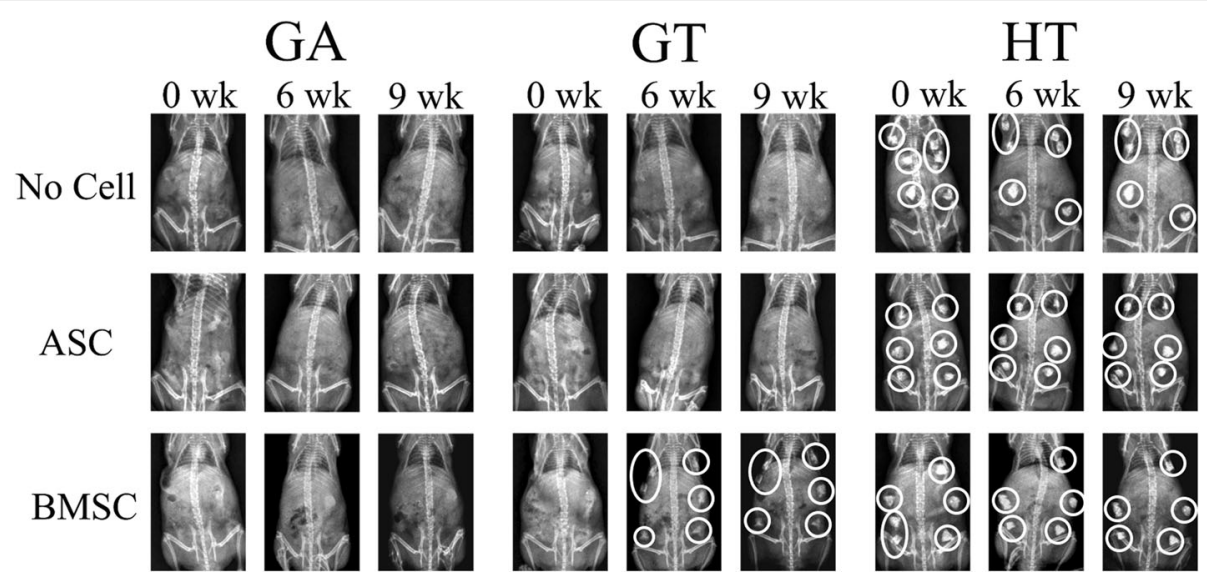

Fig. 4 Radiographs of mice with carrier scaffolds composed of tricalcium phosphate (TCP)/hydroxyapatite (HA) (HT), polyethylene glycol (PEG)/ poly-L-lactic acid (PLLA) (GA) or PEG/PLLA/TCP/HA (GT) with no cells or equine adipose-derived multipotent stromal cells (ASCs) or bone marrowderived multipotent stromal cells (BMSCs) 0, 6, and 9 weeks after surgical implantation. White circles surround radiopaque implants

lowest in HT-BMSC constructs (Fig. 10a, b). The OPG in GA-ASC constructs was higher and lower than GT- and HT-ASC constructs, respectively. The BSP was lower in HT- versus GA- and GT-ASC constructs. Additionally, GT-BMSC constructs had higher BSP than GA-BMSC constructs.

\section{Murine}

Osteogenic gene expression tended to be highest in scaffolds with BMSCs compared to those with no cells or ASCs. Differences among scaffold compositions varied and tended to parallel the equine gene expression. Among cell tissue source within scaffold composition, the highest expression levels included ALP in GA- and GT-BMSC constructs (Fig. 11a), OCN in all BMSC constructs (Fig. 11b), OPG in GT-BMSC constructs (Fig. 11c), and BSP in GT- and HT-BMSC constructs. Lowest expression levels included ALP expression in
GT-ASC constructs (Fig. 11a) and BSP in all scaffolds without cells (Fig. 11d). Among scaffold compositions, ALP tended to be lower in GA and GT versus HT scaffolds with ASCs or without cells, and in HT versus GA and GT scaffolds with BMSCs (Fig. 11a). The OPG expression followed the same general pattern with the exception that it was lower in GA- versus HT-BMSC constructs (Fig. 11b). The BSP was highest in HT scaffolds without cells and lowest in GA-BMSC constructs.

\section{Light microscopy: microstructure}

Regardless of composition, scaffolds with cells had more ECM than those without; most ECM deposition was on the implant periphery, and osteoid was apparent in all BMSC constructs. Specific to constructs, there was more amorphous, proteinaceous ECM apparent on GT- versus GA-ASC constructs, and GT-BMSC constructs had more osteoid ECM than GA-BMSC constructs (Fig. 12).

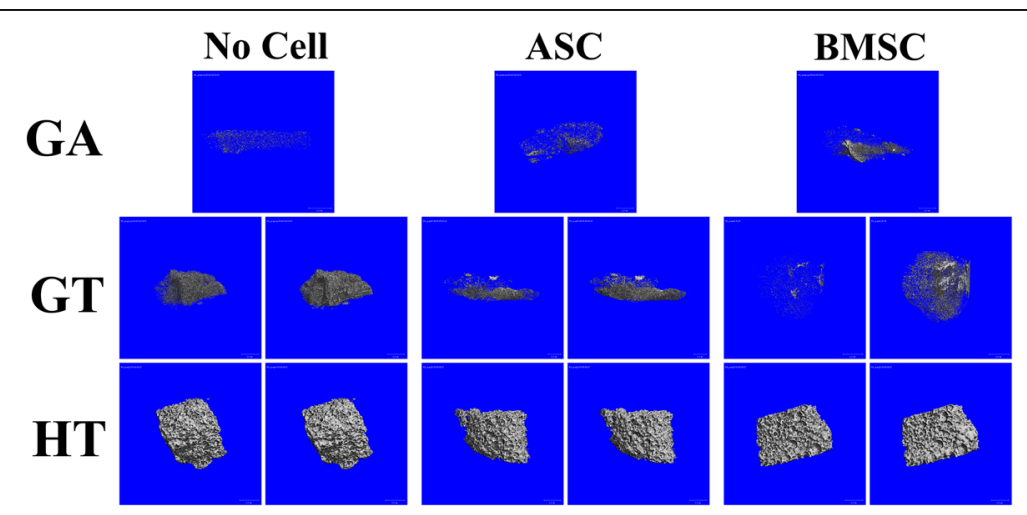

Fig. 5 Three-dimensional explant reconstructions demonstrating models generated with high (left) and low (right) thresholds to distinguish between high contrast scaffold structure (left) versus low contrast newly deposited tissue (right). A single threshold was used for GA constructs due to the limited presence of high contrast material in the specimens. ASC adipose-derived multipotent stromal cell, BMSC bone marrowderived multipotent stromal cell, GA polyethylene glycol (PEG)/poly-L-lactic acid (PLLA), GT PEG/PLLA/tricalcium phosphate (TCP)/hydroxyapatite $(H A), H T T C P / H A$ 

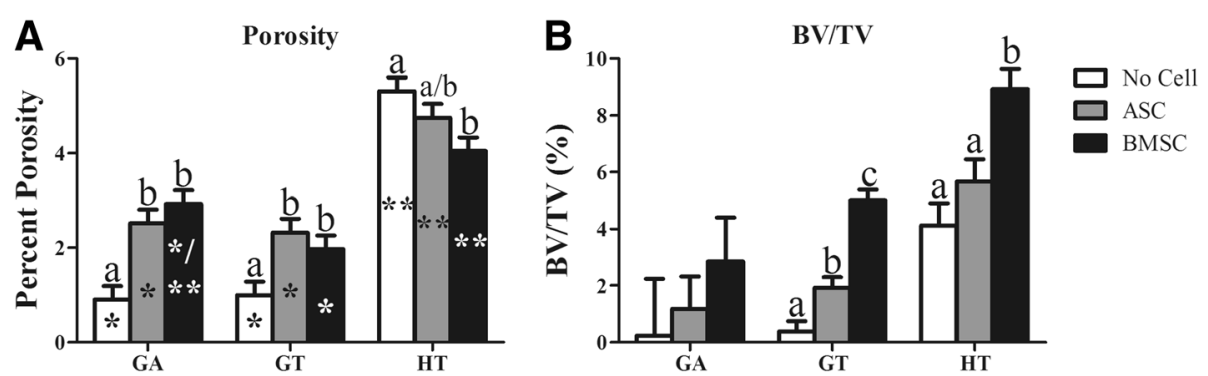

Fig. 6 Percent porosity (a) and bone volume/total volume (BV/TV; b) (mean \pm SEM) of equine ASC and BMSC constructs 9 weeks after subcutaneous implantation in a murine model. Columns with distinct superscripts are significantly different among cell tissue source within scaffolds and those with different asterisk $\left(^{*}\right)$ numbers are significantly different among scaffolds within cell tissue source $(p<0.05)$. ASC adiposederived multipotent stromal cell, BMSC bone marrow-derived multipotent stromal cell, GA polyethylene glycol (PEG)/poly-L-lactic acid (PLLA), GT PEG/PLLA/tricalcium phosphate (TCP)/hydroxyapatite (HA), HT TCP/HA

\section{Discussion}

The overall conclusions from this study are that addition of mineral to polymer scaffolds enhances equine MSC osteogenesis over polymer alone, but mineral (HT) scaffolds provide superior support for equine MSC osteogenesis compared to either polymer composition. Parallel outcomes disprove both parts of the first hypothesis since osteogenesis was best on HT scaffolds regardless of cell tissue source, and BMSCs showed more robust osteogenesis than ASCs. Furthermore, GT scaffolds better supported osteogenic differentiation and ECM deposition than GA. However, the second hypothesis that the scaffolds with MSCs have greater osteogenesis than those without is true.

Equine fracture treatment can be more difficult than other species, in part due to their unique anatomy and obligatory quadrupedal gait and stance [47]. As in other species, autologous bone grafts are an established standard to augment and facilitate fracture healing [4]. The grafts vary in quality and quantity, and have harvest morbidity [48]. There are a number of synthetic graft options including cement, calcium phosphate based ceramics [49], polymers [20], bioglass [50], and metals [51], but few have been investigated for use in the horse, in part due to cost and inadequate mechanical properties [47]. Published studies evaluating the benefits of autologous equine MSCs to promote fracture healing have focused on clinical outcomes and stable fracture healing [52]. A challenge to clinical application of MSCs to the fracture site is a standardized, cost effective carrier scaffold [53]. The work in this series of investigations
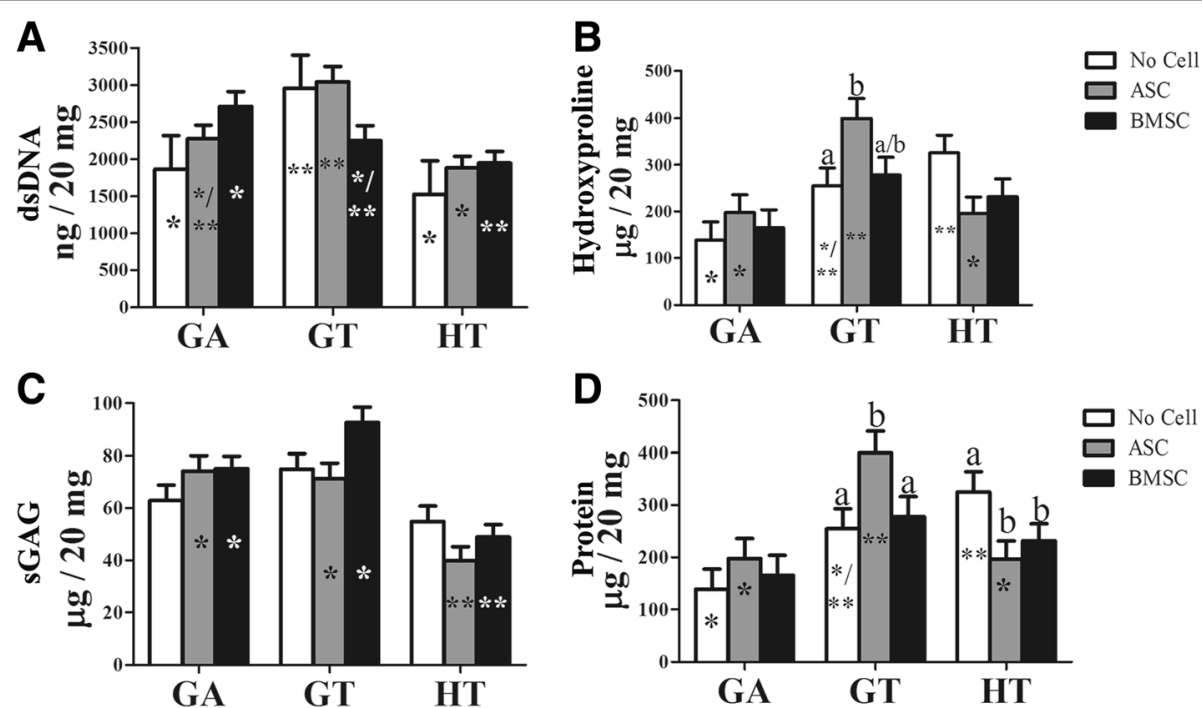

Fig. 7 The double-stranded DNA (dsDNA; a), hydroxyproline (collagen; b), sulfated glycosaminoglycan (sGAG; $\mathbf{c}$ ) and protein (d) content (mean \pm SEM) in equine ASC and BMSC constructs 9 weeks after subcutaneous implantation in a murine model. Columns with distinct superscripts are significantly different among cell types within scaffolds and those with different asterisk $\left(^{*}\right)$ numbers are significantly different among scaffolds within cell types $(p<0.05)$. ASC adipose-derived multipotent stromal cell, BMSC bone marrow-derived multipotent stromal cell, GA polyethylene glycol (PEG)/poly-L-lactic acid (PLLA), GT PEG/PLLA/tricalcium phosphate (TCP)/hydroxyapatite (HA), HT TCP/HA 


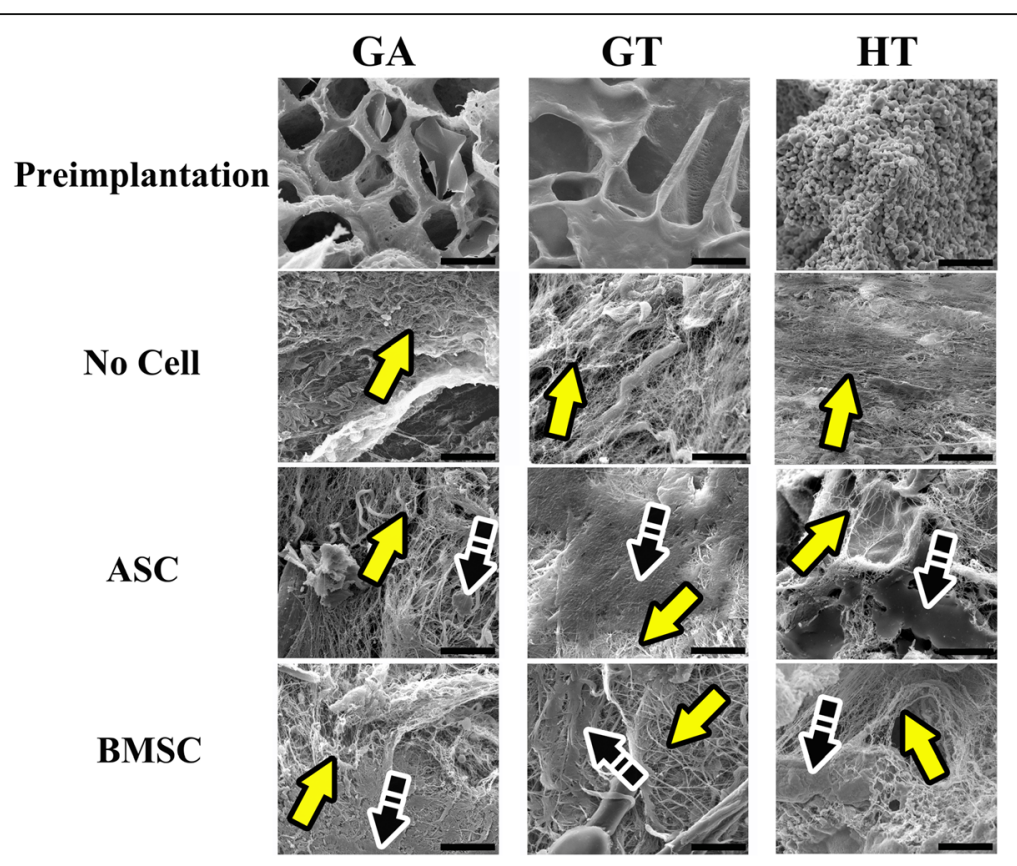

Fig. 8 Scanning electron photomicrographs of scaffolds before cell loading (preimplantation) and 9 weeks after implantation without (no cell) or combined with equine ASCs or BMSCs. Magnification = 3000x; scale bar $=20 \mu \mathrm{m}$. Yellow arrows show collagen fibrils; black arrows show solid (mineralizing) region. ASC adipose-derived multipotent stromal cell, BMSC bone marrow-derived multipotent stromal cell, GA polyethylene glycol (PEG)/poly-L-lactic acid (PLLA), GT PEG/PLLA/tricalcium phosphate (TCP)/hydroxyapatite (HA), HT TCP/HA

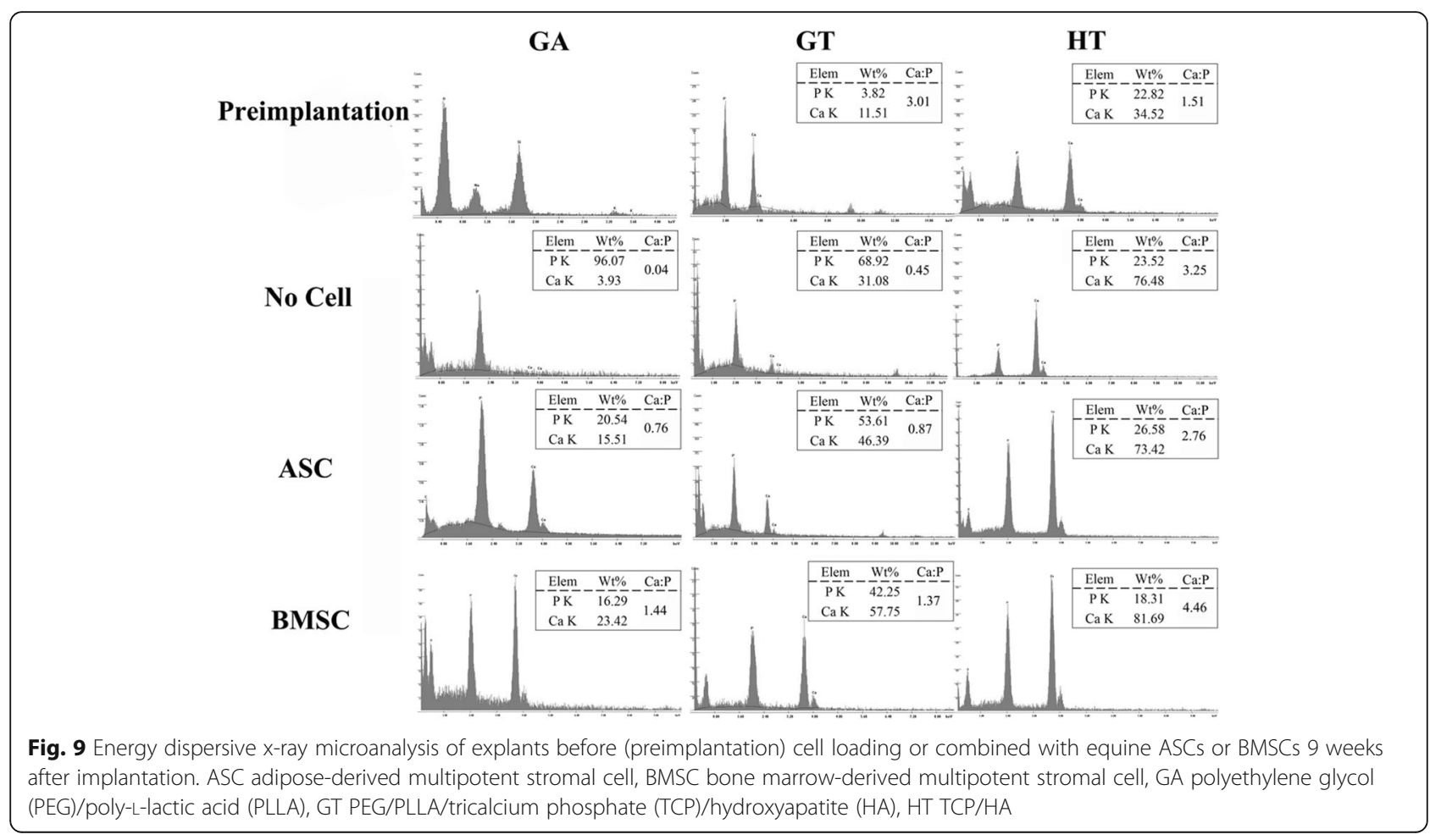




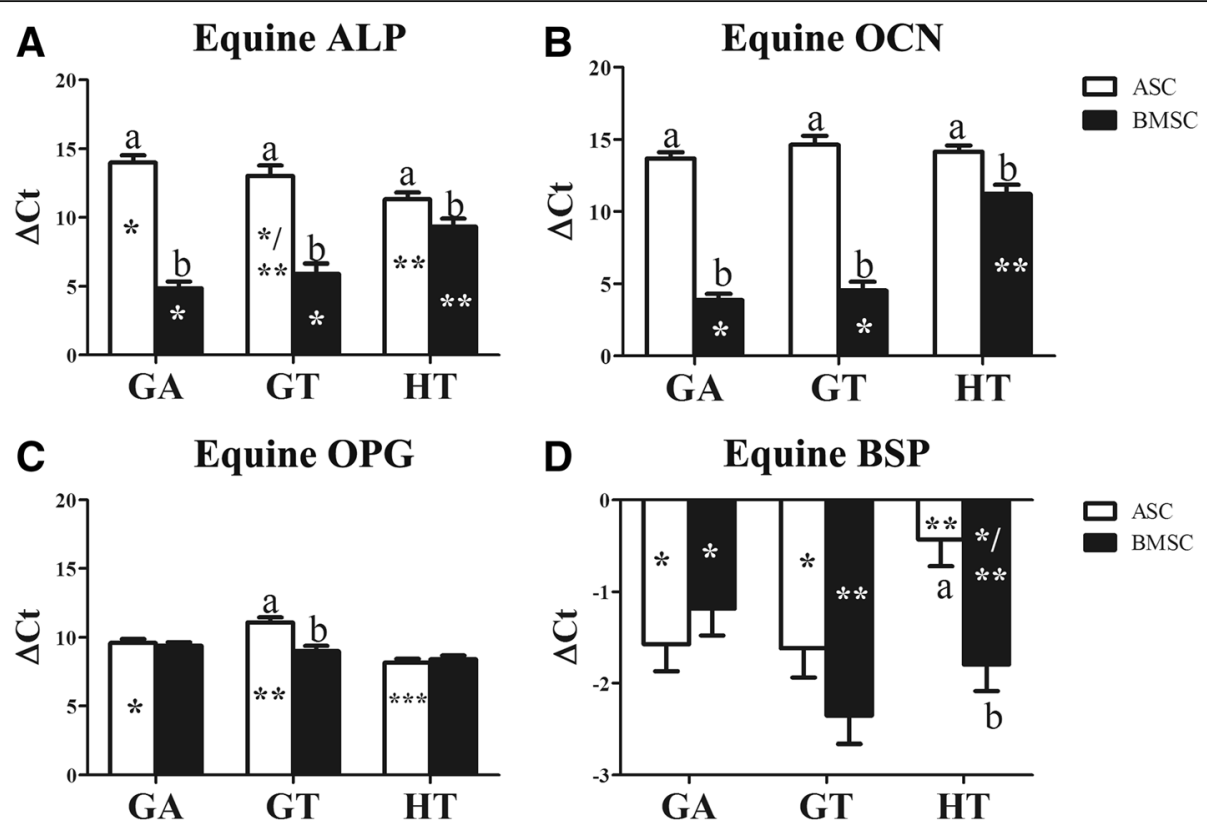

Fig. 10 Equine alkaline phosphatase (ALP; a), osteocalcin (OCN; b), osteoprotegerin (OPG; c), and bone sialoprotein (BSP; $\mathbf{d}$ ) levels (mean \pm SEM) in equine MSC-scaffold constructs 9 weeks after implantation. Columns with distinct superscripts are significantly different between cell tissue source among scaffolds and those with different asterisk $\left(^{*}\right)$ numbers are significantly different among scaffolds between cell tissue source $(p<0.05)$. ASC adipose-derived multipotent stromal cell, BMSC bone marrow-derived multipotent stromal cell, GA polyethylene glycol (PEG)/poly-L-lactic acid (PLLA), GT PEG/PLLA/tricalcium phosphate (TCP)/hydroxyapatite (HA), HT TCP/HA
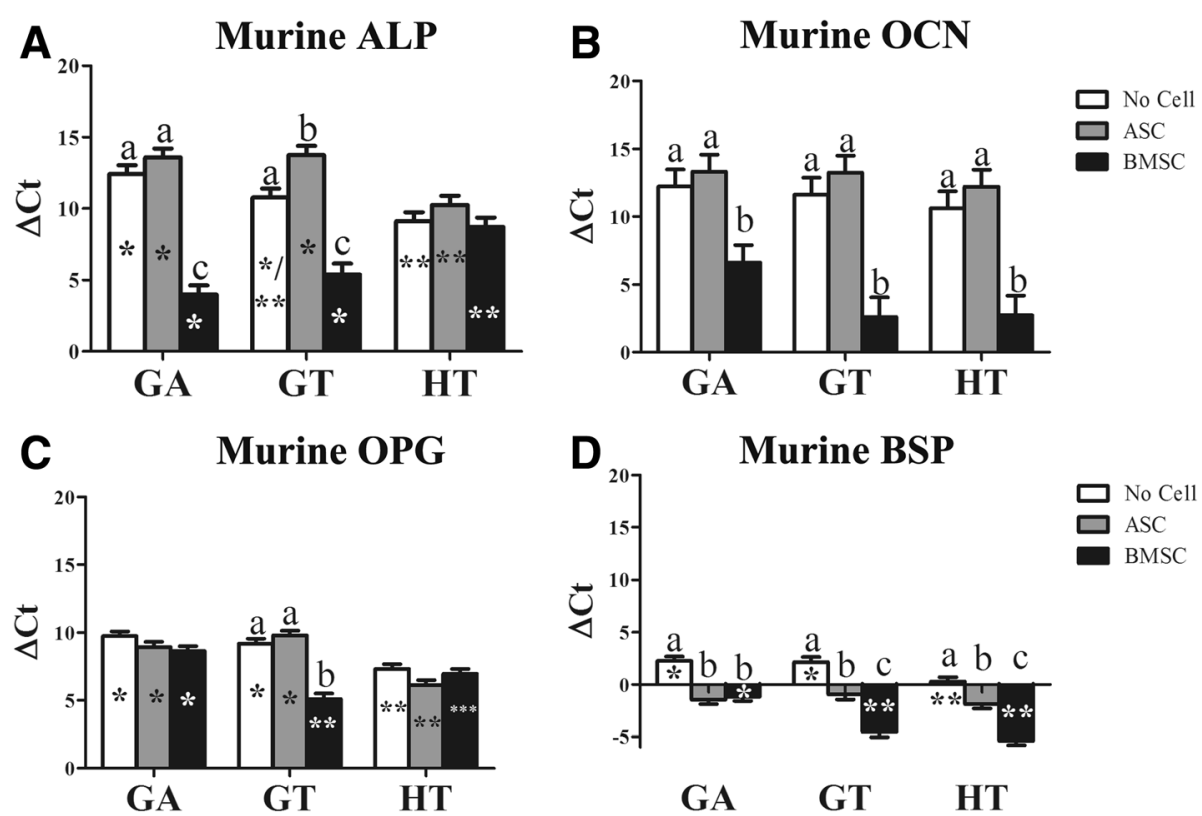

Fig. 11 Murine alkaline phosphatase (ALP; a), osteocalcin (OCN; b), osteoprotegerin (OPG; $\mathbf{c}$ ), and bone sialoprotein (BSP; d) levels (mean \pm SEM) in equine MSC-scaffold constructs 9 weeks after implantation. Columns with distinct superscripts are significantly different between cell tissue source among scaffolds and those with different asterisk $\left(^{*}\right)$ numbers are significantly different among scaffolds between cell tissue source $(p<0.05)$. ASC adipose-derived multipotent stromal cell, BMSC bone marrow-derived multipotent stromal cell, GA polyethylene glycol (PEG)/poly-L-lactic acid (PLLA), GT PEG/PLLA/tricalcium phosphate (TCP)/hydroxyapatite (HA), HT TCP/HA 


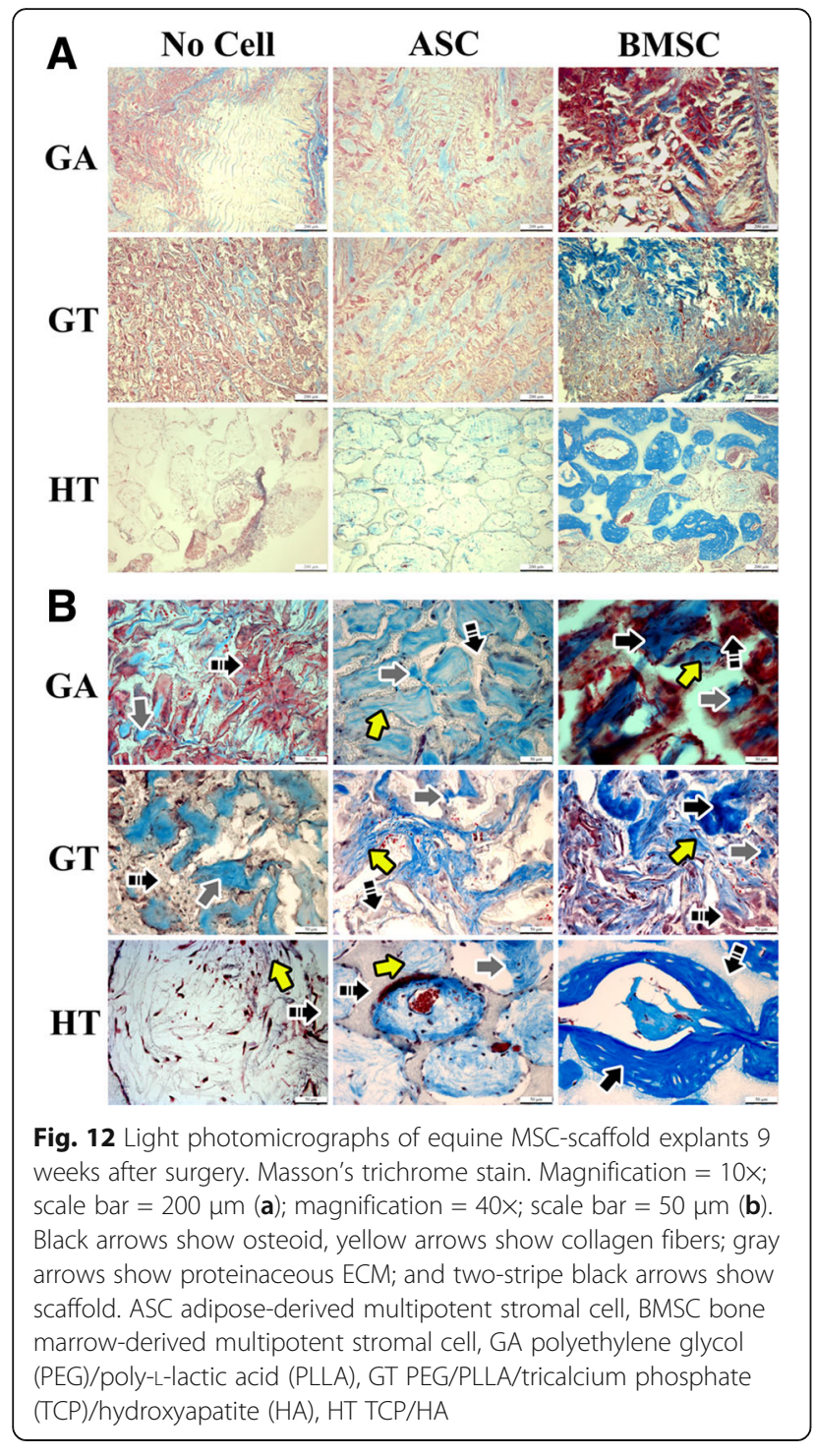

was designed to expand current knowledge base of potential graft materials to support equine MSC contributions to fracture healing. The results clearly demonstrate the potential for a scaffold composed of polymer and mineral to serve as bone graft material with and without MSCs. Polymer-mineral scaffolds may overcome some current limitations of available synthetic and autologous bone grafts and provide a standard mechanism for clinical application of MSCs for equine fracture therapy. This study also confirms the presence of exogenous mRNA in implants 9 weeks after placement. Most previous work confirms the persistence of implanted cells with inert cell labels or plasmid gene expression that can be incorporated into endogenous cells following exogenous cell senescence [54]. Few studies confirm the presence of exogenous mRNA to suggest, if not confirm, viable cell osteogenic gene expression. Another major finding is the largely parallel equine and murine genetic expression, including higher osteogenic gene expression by murine cells in BMSC constructs. Higher osteogenic potential of BMSCs compared to ASCs is consistent with established information and largely attributed to epigenetic factors $[6,55]$. Observed upregulation of osteogenic gene expression by murine cells in equine BMSC constructs may be a consequence of both growth factor production, ECM deposition, and direct and indirect signaling by exogenous cells [56-60]. These findings are consistent with the knowledge of native cell recruitment and direction by MSC implants $[9,61]$, and they further emphasize the need to construct implants for optimum direction of both exoand endogenous cell contributors to osteogenesis.

Study findings and current knowledge show that the polymer-mineral scaffold support of equine MSC osteogenesis will be improved with further optimization. Previous reports indicate that the addition of mineral to polymer scaffolds enhances MSC osteogenesis in other species, sometimes more than mineral alone $[14,45,62]$. A biomimetic environment is created, in part, by composition, surface topography, microarchitecture and mechanical properties [9]. Flexible polymer scaffolds with less structural organization in this study may have weaker osteogenic signaling than the rigid, porous ceramic structure. Calcium ions released from calcium phosphate-based minerals play a major role in influencing osteoblastic differentiation [63], and the presence of either HA or TCP enhances mRNA levels of BSP in human BMSCs without osteogenic medium [64]. Unsintered calcium phosphate with low crystallinity similar to that in this study enhance scaffold mechanical properties and contribute to human ASC osteogenic differentiation [38]. The crystals release calcium more quickly than sintered micro- or macroscale counterparts owing to more rapid dissolution [65]. Based on equine MSC osteogenic gene expression on scaffolds with calcium phosphate (HA and TCP) in this study and on collagen in previous work, polymer scaffolds with three-dimensional bone microstructure overlaid with minerals and collagen may better support osteogenesis $[8,66]$. Scaffolds specifically designed for ASC osteogenesis could also possibly increase contributions to osteogenesis.

Higher ECM and osteoid deposition on the scaffold periphery may have resulted from cell distribution and in vivo conditions. Cell distribution was not confirmed, so cells may have concentrated on the scaffold periphery from spinner flask centrifugal forces and lack of continuous scaffold pores [67-70]. Better interstitial flow on the construct surface in vivo could have promoted better cell survival than in the center, despite small implant size $[20,30,71]$. While not directly translatable to in vivo, 
reduced in-vitro MSC numbers at 7 and 21 days compared to the initial number in half of the constructs may account for the lower in-vivo ECM deposition. The cause of the cell loss was not evaluated, but increased cell numbers in some scaffolds is inconsistent with scaffold cytotoxicity. The MSC affinity for culture plastic in vitro or surrounding tissues in vivo may have been equal or greater than that for scaffold components [72, 73]. Explant dsDNA content does not suggest cell loss is likely due to murine cells from the local environment in vivo. Future studies to evaluate cell distribution and orthotopic ECM deposition will help resolve these points.

The presence of equine MSCs significantly enhanced ECM deposition in scaffolds regardless of composition, although scanning electron microscopy and light microscopy confirmed osteoid deposition was highest with either BMSCs and/or high scaffold mineral content. Changes in EDS calcium and phosphate may indicate early ion deposition for mineralization [74]. Compositional analysis confirmed proteinaceous ECM in MSC constructs that was observed with light microscopy. A lower ECM composition in HT constructs is likely from ECM deposition throughout GT and GA scaffolds versus HT scaffold pore surfaces. The HT scaffold porosity may have decreased from ECM deposition within pores and polymer scaffold porosity increased from ECM deposition and organization.

The results of this study are limited to ectopic versus orthotopic ossification that is more representative of implant efficacy to support osteogenesis in native bone $[75,76]$. Athymic mice have diminished osteogenic capabilities compared to immunocompetent animals [77], so scaffolds and cell-scaffold constructs may behave differently in an equine fracture. Nonetheless, subcutaneous implantation is an accepted approach with numerous intra-animal replicates to compare in vivo ECM deposition and genetic expression among scaffolds and cell-scaffold constructs $[78,79]$. The study length exceeded the time for natural, early fracture stabilization [80] to evaluate long-term differences in cell-construct in vivo behaviors. Results that differ between this and other studies can be attributable to study duration, distinct in vivo and in vitro environments [81, 82], species [83, 84], and revitalized MSCs, a point that has been shown to impact cell behavior $[85,86]$ within immunophenotypes $[87,88]$. Nonetheless, the number of sample replicates, duration, and parallel outcome measures in this study provide robust tests of the stated hypotheses.

The scaffolds used in the present study have been rarely studied in equine medicine due to the fact that bone graft study in veterinary medicine is far behind that in human medical research [81]. In equine medicine, the major bone graft sources are fresh, autogenous cancellous bone, and tissue engineered bone graft is a relatively new field. In our present study, this is the first time the polymeric-inorganic scaffold has been used to investigate a potential application in equine bone tissue engineering through in vitro and vivo evaluation. The presence of equine-specific mRNA confirm the contribution of equine MSCs after implantation. The addition of minerals to polymeric materials holds promising potential for an equine bone tissue engineering application. Additionally, the survival of implanted equine cells and the recruitment of murine MSCs provides strong support for MSCbased therapy for equine bone fracture treatment.

\section{Conclusions}

These in-vivo study results confirm that addition of minerals to polymer carrier scaffold enhances strong osteogenic capabilities of equine MSCs without osteogenic preconditioning prior to implantation, and that BMSCs appear to have better osteogenic ECM production and organization than ASCs. Findings from these investigations confirm that contributions of both exogenous cells and recruitment of host MSCs are vital to MSC construct osteogenesis. The contributions in the present study may provide important information to help overcome equine bone healing challenges. The novel scaffold carriers evaluated in this study are appropriate for continued development of synthetic graft materials and viable tissue implants to augment equine fracture strategies.

\section{Abbreviations}

$\mu C T$ : Microcomputed tomography; ALP: Alkaline phosphatase; ASC: Adiposederived multipotent stromal cell; BMSC: Bone marrow-derived multipotent stromal cell; BSA: Bovine serum albumin; BSP: Bone sialoprotein; BV/TV: Bone volume/total volume; DMEM/F-12: Dulbecco's modified Eagle's medium F-12; DMMB: Dimethylmethylene blue; DMSO: Dimethyl sulfoxide; ds: Double-

stranded; ECM: Extracellular matrix; EDS: Energy-dispersive x-ray spectroscopy; EDTA: Ethylenediaminetetraacetic acid; FBS: Fetal bovine serum; GA: PEG/

PLLA; GAPDH: Glyceraldehyde 3-phosphate dehydrogenase; GT: PEG/PLLA/ TCP/HA; HA: Hydroxyapatite; HT: TCP/HA; IgG: Immunoglobulin;

IV: Intravenously; MSC: Multipotent stromal cell; MTT: 3-(4,5-Dimethylthiazol2-yl)-2,5-diphenyl tetrazolium bromide; MW: Molecular weight;

OCN: Osteocalcin; OPG: Osteoprotegerin; P: Passage; PBS: Phosphate-buffered saline; PEG: Polyethylene glycol; PLLA: Poly-L-lactic acid; RT-PCR: Real-time polymerase chain reaction; SEM: Standard error of the mean; SGAG: Sulfated glycosaminoglycan; SVF: Stromal vascular fraction; TCP: Tricalcium phosphate

\section{Acknowledgements}

The authors would like to thank Dr. Lin Xie and Ms. Marilyn Dietrich for assistance with data collection.

\section{Funding}

This work was funded in part by the Grayson-Jockey Club Research Foundation and the Louisiana State University School of Veterinary Medicine Equine Health Studies and Competitive Organized Research Programs.

\section{Availability of data and materials}

The data sets used and/or analyzed during the current study are available from the corresponding author on reasonable request. 


\section{Authors' contributions}

WD contributed to data collection, data reduction, data analysis, data interpretation, preparation of the manuscript, and gave final approval of the manuscript. CC contributed to data collection, preparation of the manuscript, and gave final approval of the manuscript. MH contributed to data collection, data reduction, data analysis, and gave final approval of the manuscript. DH contributed to data collection and gave final approval of the manuscript. MJL contributed to study design, data collection, data reduction, data analysis, data interpretation, preparation of the manuscript, and gave final approval of the manuscript.

\section{Ethics approval}

All animal procedures were approved by the Louisiana State University Institutional Animal Care and Use Committee prior to study initiation (protocols \#13-050 and 07-049).

\section{Consent for publication}

Not applicable.

\section{Competing interests}

The authors declare that they have no competing interests.

\section{Publisher's Note}

Springer Nature remains neutral with regard to jurisdictional claims in published maps and institutional affiliations.

\section{Author details}

'Laboratory for Equine and Comparative Orthopedic Research, Louisiana State University, Baton Rouge, LA, USA. ${ }^{2}$ Department of Biomedical Engineering, Pennsylvania State University, University Park, PA, USA.

Received: 27 July 2017 Revised: 17 January 2018 Accepted: 23 January 2018 Published online: 09 March 2018

\section{References}

1. Laurencin C, Khan Y, El-Amin SF. Bone graft substitutes. Expert Rev Med Devices. 2006:3:49-57.

2. Matsushima A, Kotobuki N, Tadokoro M, Kawate K, Yajima H, Takakura Y, Ohgushi H. In vivo osteogenic capability of human mesenchymal cells cultured on hydroxyapatite and on $\beta$-tricalcium phosphate. Artif Organs. 2009:33:474-81.

3 Wu S, Liu X, Yeung KW, Liu C, Yang X. Biomimetic porous scaffolds for bone tissue engineering. Mater Sci Eng R Rep. 2014;80:1-36.

4 García-Gareta E, Coathup MJ, Blunn GW. Osteoinduction of bone grafting materials for bone repair and regeneration. Bone. 2015;81:112-21.

5 Vidal MA, Kilroy GE, Johnson JR, Lopez MJ, Moore RM, Gimble JM. Cell growth characteristics and differentiation frequency of adherent equine bone marrow-derived mesenchymal stromal cells: adipogenic and osteogenic capacity. Vet Surg. 2006;35:601-10.

6 Vidal MA, Kilroy GE, Lopez MJ, Johnson JR, Moore RM, Gimble JM. Characterization of equine adipose tissue-derived stromal cells: adipogenic and osteogenic capacity and comparison with bone marrow-derived mesenchymal stromal cells. Vet Surg. 2007;36:613-22.

7 Im G-I, Shin Y-W, Lee K-B. Do adipose tissue-derived mesenchymal stem cells have the same osteogenic and chondrogenic potential as bone marrow-derived cells? Osteoarthr Cartil. 2005;13:845-53.

8 Xie L, Zhang N, Marsano A, Vunjak-Novakovic G, Zhang Y, Lopez MJ. In vitro mesenchymal trilineage differentiation and extracellular matrix production by adipose and bone marrow derived adult equine multipotent stromal cells on a collagen scaffold. Stem Cell Rev. 2013;9:858-72.

9 Stevens MM. Biomaterials for bone tissue engineering. Mater Today. 2008; 11:18-25.

10 Bose S, Roy M, Bandyopadhyay A. Recent advances in bone tissue engineering scaffolds. Trends Biotechnol. 2012;30:546-54.

11 Simmons CA, Alsberg E, Hsiong S, Kim WJ, Mooney DJ. Dual growth factor delivery and controlled scaffold degradation enhance in vivo bone formation by transplanted bone marrow stromal cells. Bone. 2004;35:562-9.

12 LeGeros RZ. Calcium phosphate-based osteoinductive materials. Chem Rev. 2008;108:4742-53.
13 Gan Y, Dai K, Zhang P, Tang T, Zhu Z, Lu J. The clinical use of enriched bone marrow stem cells combined with porous beta-tricalcium phosphate in posterior spinal fusion. Biomaterials. 2008;29:3973-82.

14 McCullen S, Zhu Y, Bernacki S, Narayan R, Pourdeyhimi B, Gorga R, Loboa E. Electrospun composite poly (L-lactic acid)/tricalcium phosphate scaffolds induce proliferation and osteogenic differentiation of human adiposederived stem cells. Biomed Mater. 2009;4:035002.

15 Dorozhkin SV. Calcium orthophosphate bioceramics. Ceram Int. 2015;41:13913-66.

16 Hu Y, Zhang C, Zhang S, Xiong Z, Xu J. Development of a porous poly (Llactic acid)/hydroxyapatite/collagen scaffold as a BMP delivery system and its use in healing canine segmental bone defect. J Biomed Mater Res A. 2003;67:591-8.

17 Schellekens H, Hennink WE, Brinks V. The immunogenicity of polyethylene glycol: facts and fiction. Pharm Res. 2013;30:1729-34.

18 Tong R, Gabrielson NP, Fan TM, Cheng J. Polymeric nanomedicines based on poly (lactide) and poly (lactide-co-glycolide). Curr Opinion Solid State Mater Sci. 2012;16:323-32

19 Fitzgerald R, Vleggaar D. Using poly-L-lactic acid (PLLA) to mimic volume in multiple tissue layers. J Drugs Dermatol. 2009;8:s5-14.

20 Liu X, Ma PX. Polymeric scaffolds for bone tissue engineering. Ann Biomed Eng. 2004;32:477-86

21 Danoux CB, Barbieri D, Yuan H, de Bruijn JD, van Blitterswijk CA, Habibovic P. In vitro and in vivo bioactivity assessment of a polylactic acid/hydroxyapatite composite for bone regeneration. Biomatter. 2014:4:e27664.

22 Barbieri D, Yuan H, Luo X, Farè S, Grijpma DW, de Bruijn JD. Influence of polymer molecular weight in osteoinductive composites for bone tissue regeneration. Acta Biomater. 2013;9:9401-13.

23 Shah S, Zhu K, Pitt C. Poly-DL-lactic acid: polyethylene glycol block copolymers. The influence of polyethylene glycol on the degradation of poly-DL-lactic acid. J Biomater Sci Polym Ed. 1994;5:421-31.

24 Woo KM, Seo J, Zhang R, Ma PX. Suppression of apoptosis by enhanced protein adsorption on polymer/hydroxyapatite composite scaffolds. Biomaterials. 2007;28:2622-30.

$25 \mathrm{Ma}$ PX, Zhang R, Xiao G, Franceschi R. Engineering new bone tissue in vitro on highly porous poly (a-hydroxyl acids)/hydroxyapatite composite scaffolds. J Biomed Mater Res. 2001;54:284-93.

26 Milner PI, Clegg PD, Stewart MC. Stem cell-based therapies for bone repair. Vet Clin N Am Equine Pract. 2011;27:299-314.

27 Sittinger M, Hutmacher DW, Risbud MV. Current strategies for cell delivery in cartilage and bone regeneration. Curr Opin Biotechnol. 2004;15:411-8.

28 Martin I, Wendt D, Heberer M. The role of bioreactors in tissue engineering. Trends Biotechnol. 2004;22:80-6.

29 Grottkau BE, Lin Y. Osteogenesis of adipose-derived stem cells. Bone Res. 2013;1:133-45.

30 Plunkett N, O'Brien FJ. Bioreactors in tissue engineering. Technol Health Care. 2011:19:55-69.

31 Sladkova M, de Peppo GM. Bioreactor systems for human bone tissue engineering. Processes. 2014;2:494-525.

32 Arnsdorf EJ, Tummala P, Kwon RY, Jacobs CR. Mechanically induced osteogenic differentiation - the role of RhoA, ROCKII and cytoskeletal dynamics. J Cell Sci. 2009;122:546-53.

33 Arnsdorf EJ, Tummala P, Jacobs CR. Non-canonical Wnt signaling and $\mathrm{N}$ cadherin related $\beta$-catenin signaling play a role in mechanically induced osteogenic cell fate. PLoS One. 2009:4:e5388.

34 Bara JJ, McCarthy HE, Humphrey E, Johnson WE, Roberts S. Bone marrowderived mesenchymal stem cells become antiangiogenic when chondrogenically or osteogenically differentiated: implications for bone and cartilage tissue engineering. Tissue Eng A. 2013;20:147-59.

35 Lopez MJ, Jarazo J. State of the art: stem cells in equine regenerative medicine. Equine Vet J. 2015:47:145-54.

36 Koch TG, Berg LC, Betts DH. Current and future regenerative medicineprinciples, concepts, and therapeutic use of stem cell therapy and tissue engineering in equine medicine. Can Vet J. 2009:50:155-65.

37 Taylor S, Smith R, Clegg P. Mesenchymal stem cell therapy in equine musculoskeletal disease: scientific fact or clinical fiction? Equine Vet J. 2007; 39:172-80.

38 Smoak M, Hogan K, Kriegh L, Chen C, Terrell LB, Qureshi AT, Monroe WT, Gimble JM, Hayes DJ. Modulation of mesenchymal stem cell behavior by nano-and micro-sized $\beta$-tricalcium phosphate particles in suspension and composite structures. J Nanopart Res. 2015;17:182. 
39 Lee JE, Kim KE, Kwon IC, Ahn HJ, Lee S-H, Cho H, Kim HJ, Seong SC, Lee MC. Effects of the controlled-released TGF- $\beta 1$ from chitosan microspheres on chondrocytes cultured in a collagen/chitosan/glycosaminoglycan scaffold. Biomaterials. 2004;25:4163-73.

40 Vidal MA, Robinson SO, Lopez MJ, Paulsen DB, Borkhsenious O, Johnson JR, Moore RM, Gimble JM. Comparison of chondrogenic potential in equine mesenchymal stromal cells derived from adipose tissue and bone marrow. Vet Surg. 2008;37:713-24.

41 Spencer ND, Chun R, Vidal MA, Gimble JM, Lopez MJ. In vitro expansion and differentiation of fresh and revitalized adult canine bone marrow-derived and adipose tissue-derived stromal cells. Vet J. 2012;191:231-9.

42 Stegemann H, Stalder K. Determination of hydroxyproline. Clin Chim Acta. 1967;18:267-73.

43 Enobakhare BO, Bader DL, Lee DA. Quantification of sulfated glycosaminoglycans in chondrocyte/alginate cultures, by use of 1,9dimethylmethylene blue. Anal Biochem. 1996;243:189-91.

44 Hartree EF. Determination of protein: a modification of the Lowry method that gives a linear photometric response. Anal Biochem. 1972;48:422-7.

45 Zhang $P$, Hong $Z, Y u T$, Chen $X$, Jing $X$. In vivo mineralization and osteogenesis of nanocomposite scaffold of poly (lactide-co-glycolide) and hydroxyapatite surface-grafted with poly (L-lactide). Biomaterials. 2009;30:58-70.

46 Suchanek W, Yoshimura M. Processing and properties of hydroxyapatitebased biomaterials for use as hard tissue replacement implants. J Mater Res. 1998;13:94-117.

47 Nunamaker D. On bone and fracture treatment in the horse, Proceedings of the 48th of the American Association of Equine Practitionners. 2002;9-101

48 O'Malley MJ, Sayres SC, Saleem O, Levine D, Roberts M, Deland JT, Ellis S. Morbidity and Complications Following Percutaneous Calcaneal Autograft Bone Harvest, Foot \& Ankle International. 2013;35(1);30-37

49 Bohner M, Galea L, Doebelin N. Calcium phosphate bone graft substitutes: Failures and hopes. J Eur Ceram Soc. 2012;32(11):2663-2671.

50 Yuan H, de Bruijn JD, Zhang X, van Blitterswijk CA, de Groot K. Bone induction by porous glass ceramic made from Bioglass ${ }^{\circledast}(45 S 5)$. J Biomed Mater Res. 2001;58(3):270-276.

51 Matassi F, Botti A, Sirleo L, Carulli C, Innocenti M. Porous metal for orthopedics implants. Clin Cases Miner Bone Metab. 2013;10(2):111-5.

52 Borjesson DL, Peroni JF. The regenerative medicine laboratory: facilitating stem cell therapy for equine disease. Clin Lab Med. 2011;31(1):109-123.

53 Oryan A, Moshiri A, Maffulli N, Alidadi S. Bone regenerative medicine: classic options, novel strategies, and future directions. J Orthop Surg Res. 2014;9(1):18.

54 Progatzky F, Dallman MJ, Celso CL. From seeing to believing: labelling strategies for in vivo cell-tracking experiments. Interface Focus. 2013;3(3): 20130001.

55 Pizzute T, Lynch K, Pei M. Impact of tissue-specific stem cells on lineagespecific differentiation: a focus on the musculoskeletal system. Stem Cell Rev Rep. 2015;11(1):119-32.

56 Monaco E, Bionaz M, Rodriguez-Zas S, Hurley WL, Wheeler MB. Transcriptomics comparison between porcine adipose and bone marrow mesenchymal stem cells during in vitro osteogenic and adipogenic differentiation. PloS one. 2012;7(3):e32481.

57 Zhang X, Guo J, Zhou Y, Wu G. The roles of bone morphogenetic proteins and their signaling in the osteogenesis of adipose-derived stem cells, Tissue Engineering Part B: Reviews. 2013;20(1):84-92.

58 Zuk P. Adipose-derived stem cells in tissue regeneration: a review, ISRN Stem Cells 2013. (2013).

59 Roodman GD. Role of stromal-derived cytokines and growth factors in bone metastasis. Cancer. 2003;97(S3):733-738.

60 Festuccia C, Bologna M, Gravina GL, Guerra F, Angelucci A, Villanova A Millimaggi D, Teti A. Osteoblast conditioned media contain TGF- $\beta 1$ and modulate the migration of prostate tumor cells and their interactions with extracellular matrix components. Int J Cancer. 1999;81(3):395-403.

61 Kim Kl, Park S, Im Gl. Osteogenic differentiation and angiogenesis with cocultured adipose-derived stromal cells and bone marrow stromal cells. Biomater. 2014;35(17):4792-804

62 Roohani-Esfahani SI, Nouri-Khorasani S, Lu Z, Appleyard R, Zreiqat H. The influence hydroxyapatite nanoparticle shape and size on the properties of biphasic calcium phosphate scaffolds coated with hydroxyapatite-PCL composites. Biomater. 2010;31(21):5498-509.
63 Samavedi S, Whittington AR, Goldstein AS. Calcium phosphate ceramics in bone tissue engineering: a review of properties and their influence on cell behavior. Acta Biomater. 2013;9(9):8037-045

64 Polini A, Pisignano D, Parodi M, Quarto R, Scaglione S. Osteoinduction of human mesenchymal stem cells by bioactive composite scaffolds without supplemental osteogenic growth factors. PloS one. 2011;6(10):e26211.

65 Fathi M, Hanifi A, Mortazavi V. Preparation and bioactivity evaluation of bone-like hydroxyapatite nanopowder. J Mater Process Technol. 2008;202(1): 536-542.

66 Inzana JA, Olvera D, Fuller SM, Kelly JP, Graeve OA, Schwarz EM, Kates SL, Awad HA. 3D printing of composite calcium phosphate and collagen scaffolds for bone regeneration. Biomater. 2014;35(13):4026-034.

67 Sikavitsas VI, Bancroft GN, Mikos AG. Formation of three-dimensional cell/ polymer constructs for bone tissue engineering in a spinner flask and a rotating wall vessel bioreactor. J Biomed Mater Res. 2002;62(1):136-148.

68 Stiehler M, Bünger C, Baatrup A, Lind M, Kassem M, Mygind T. Effect of dynamic 3-D culture on proliferation, distribution, and osteogenic differentiation of human mesenchymal stem cells, J Biomed Mater Res Part A. 2009;89(1):96-107.

69 Hutmacher DW. Scaffolds in tissue engineering bone and cartilage. Biomater. 2000;21(24):2529-43.

70 Amini AR, Laurencin CT, Nukavarapu SP. Bone tissue engineering: recent advances and challenges. Crit Rev Biomed Eng. 2012;40(5):363-408.

71 Laschke MW, Harder Y, Amon M, Martin I, Farhadi J, Ring A, Torio-Padron N, Schramm R, Rücker M, Junker D. Angiogenesis in tissue engineering: breathing life into constructed tissue substitutes. Tissue Eng. 2006;12(8): 2093-2104.

72 Deligianni DD, Katsala ND, Koutsoukos PG, Missirlis YF. Effect of surface roughness of hydroxyapatite on human bone marrow cell adhesion, proliferation, differentiation and detachment strength. Biomater. 2000;22(1):87-96.

73 Dawson E, Mapili G, Erickson K, Taqvi S, Roy K. Biomaterials for stem cell differentiation. Adv Drug Deliv Rev. 2008;60(2):215-28.

74 Bonjour JP. Calcium and phosphate: a duet of ions playing for bone health. J Am Col Nutr. 2011;30(sup5):438S-448S.

75 Kruyt MC, Dhert WJ, Oner FC, van Blitterswijk CA, Verbout AJ, de Bruijn JD. Analysis of ectopic and orthotopic bone formation in cell-based tissueengineered constructs in goats. Biomater. 2007;28(10):1798-1805.

76 Scott MA, Levi B, Askarinam A, Nguyen A, Rackohn T, Ting K, Soo C, James AW. Brief review of models of ectopic bone formation. Stem Cells Dev. 2011;21(5):655-667.

77 Zhang Y, Li X, Chihara T, Mizoguchi T, Hori A, Udagawa N, Nakamura H, Hasegawa H, Taguchi A, Shinohara A. Comparing immunocompetent and immunodeficient mice as animal models for bone tissue engineering. Oral Dis. 2015:21(5):583-592.

78 Higuera GA, Hendriks HA, van Dalum J, Wu L, Schotel R, Moreira-Teixeira L, van den Doel M, Leijten JC, Riesle J, Karperien M. In vivo screening of extracellular matrix components produced under multiple experimental conditions implanted in one animal. Integr Biol. 2013;5(6):889-898.

79 Thompson EM, Matsiko A, Farrell E, Kelly DJ, O'Brien FJ. Recapitulating endochondral ossification: a promising route to in vivo bone regeneration. J Tissue Eng Regen Med. 2015;9(8):889-902.

80 Cornell CN Lane JM. Newest factors in fracture healing. Clin Orthop. 1992; 277:297-311.

81 Rizzi SC, Heath D, Coombes A, Bock N, Textor M, Downes S. Biodegradable polymer/hydroxyapatite composites: surface analysis and initial attachment of human osteoblasts. J Biomed Mater Res. 2001;55(4):475-486.

82 Peng F, Yu X, Wei M. In vitro cell performance on hydroxyapatite particles/ poly (L-lactic acid) nanofibrous scaffolds with an excellent particle along nanofiber orientation. Acta Biomater. 2011;7(6):2585-2592.

83 Montjovent MO, Mathieu L, Schmoekel H, Mark S, Bourban PE, Zambelli PY, Laurent-Applegate LA, Pioletti DP Repair of critical size defects in the rat cranium using ceramic-reinforced PLA scaffolds obtained by supercritical gas foaming, J Biomed Mater Res A. 2007:83(1):41-51.

84 Montjovent MO, Mathieu L, Hinz B, Applegate LL, Bourban PE, Zambelli PY, Månson JA, Pioletti DP. Biocompatibility of bioresorbable poly (L-lactic acid) composite scaffolds obtained by supercritical gas foaming with human fetal bone cells. Tissue Eng. 2005;11(11-12):1640-1649

85 James AW, Levi B, Nelson ER, Peng M, Commons GW, Lee M, Wu B, Longaker MT. Deleterious effects of freezing on osteogenic differentiation of human adipose-derived stromal cells in vitro and in vivo. Stem Cells Dev. 2010;20(3):427-439. 
86 Duan W, Lopez MJ. Effects of Cryopreservation on Canine Multipotent Stromal Cells from Subcutaneous and Infrapatellar Adipose Tissue. Stem Cell Rev Rep. 2016;12(2):257-268.

87 Duan W, Zhang N, Lopez MJ. Canine Adipose Tissue Derived Multipotent Stromal Cells Harvested from Infrapatellar and Subcutaneous Adipose Tissue Have Similarin Vitrobehavior. Vet Sur. 2014;43(6):E163.

88 Mitchell JB, Mclntosh K, Zvonic S, Garrett S, Floyd ZE, Kloster A, Di Halvorsen Y, Storms RW, Goh B, Kilroy G. Immunophenotype of human adiposederived cells: temporal changes in stromal-associated and stem cellassociated markers. Stem Cells. 2006;24(2):376-385.

Submit your next manuscript to BioMed Central and we will help you at every step:

- We accept pre-submission inquiries

- Our selector tool helps you to find the most relevant journal

- We provide round the clock customer support

- Convenient online submission

- Thorough peer review

- Inclusion in PubMed and all major indexing services

- Maximum visibility for your research

Submit your manuscript at www.biomedcentral.com/submit
Biomed Central 